Check for updates

Cite this: RSC Adv., 2020, 10, 5777

Received 2nd September 2019

Accepted 24th January 2020

DOI: $10.1039 / c 9 r a 07009 e$

rsc.li/rsc-advances

\section{Benzyl salicylate from the stems and stem barks of Cornus walteri as a nephroprotective agent against cisplatin-induced apoptotic cell death in LLC-PK1 cells $\dagger$}

\begin{abstract}
Dahae Lee, ${ }^{a}$ Seoung Rak Lee, ${ }^{a}$ Ki Sung Kang*b and Ki Hyun Kim (D)*a
Nephrotoxicity currently plagues the therapeutic use of cisplatin. Its major side effects are predominantly associated with renal tubular cell apoptosis. In this study, we examined the potential nephroprotective constituents from $C$. walteri that can exert effects against cisplatin-induced oxidative stress and apoptosis in renal tubular epithelial (LLC-PK1) cells. Phytochemical investigation of the MeOH extract of the stems and stem barks of $C$. walteri led to the isolation of the potential nephroprotective constituents (1-15). Among the isolates, treatment with benzyl salicylate (BS) (15) (50 and $100 \mu \mathrm{M}$ ) significantly attenuated LLC-PK1 cell apoptosis and potently blocked cisplatin-induced nuclei condensation, intracellular ROS generation, and apoptosis, as indicated by Hoechst 33342 and $\mathrm{H}_{2}$ DCFDA staining. Furthermore, the expression of apoptosis-related proteins such as MAPK, Bax/Bcl-2 protein ratio, and cleaved caspase- 9 and -3 , were significantly decreased by BS. These findings provide that benzyl salicylate can be a nephroprotective agent against cisplatin-induced oxidative stress and apoptosis.
\end{abstract}

\section{Introduction}

Cisplatin (cis-diamminedichloroplatinum(II), CDDP) is very efficacious as a first-line therapy for malignant tumors in organs such as the testis, head, and ovaries. ${ }^{\mathbf{1} 2}$ However, cisplatin treatment results in not only the damage of tumor cells but also the tissue cells. ${ }^{3}$ Cisplatin is especially toxic to the proximal tubule cells of the kidney, resulting in kidney dysfunction. ${ }^{4}$ Recent cisplatin-targeted nephroprotection studies have focused on the search for natural products with enormous structural and chemical diversity, ${ }^{5,6}$ because reducing cisplatininduced nephrotoxicity will not only maximize its clinical outcomes, but can be beneficial to patients receiving cisplatin chemotherapy.

Cornus walteri Wanger, well-known as Walter's dogwood, is a deciduous shrub belonging to the family Cornaceae. C. walteri is distributed in Asian countries, specifically China and Korea as an economic crop. This tree is best known as a raw material for high-grade furniture and agricultural tools. It is also cultivated for its showy, edible berries. Traditionally, its fruits and leaves are used to treat dermatologic inflammation caused by

${ }^{a}$ School of Pharmacy, Sungkyunkwan University, Suwon 440-746, Republic of Korea. E-mail: khkim83@skku.edu; Fax: +82-31-290-7730; Tel: +82-31-290-7700

${ }^{b}$ College of Korean Medicine, Gachon University, Seongnam 13120, Republic of Korea. E-mail: kkang@gachon.ac.kr; Tel: +82-31-750-5402

$\dagger$ Electronic supplementary information (ESI) available: Protective effects of compounds 1-15 on the viability of cisplatin-damaged LLC-PK1 cells. See DOI: 10.1039/c9ra07009e lacquer poison, as indicated in the Chinese Materia Medica. ${ }^{7}$ Its leaves are used as an antidiarrheal in Korean folk medicine. ${ }^{8}$ According to previous phytochemical studies, C. walteri possesses a variety of bioactive secondary metabolites such as lignans, isoquercitrin, and triterpenoids. ${ }^{9-11}$ The extract of $C$. walteri has also been shown to inhibit NO production in lipopolysaccharide (LPS)-activated RAW 264.7 macrophages. ${ }^{12}$ The leaves of this plant also have protective effects against UVBinduced photoaging in human reconstituted skin. ${ }^{7}$ However, the stem of $C$. walteri has not been under-developed and utilized.

In our continued quest to discover biologically novel natural products from a variety of Korean natural resources, ${ }^{13-17}$ our group has explored the potential bioactive constituents of $C$. walteri. ${ }^{11,18,19}$ Our previous studies reported that the $\mathrm{MeOH}$ extract of the stems and stem barks of $C$. walteri are significantly cytotoxic. ${ }^{11}$ The cytotoxic effects of triterpenoids and $\delta$-valerolactones have also been elucidated in the our studies. ${ }^{\mathbf{1 1 , 1 8 , 1 9}}$ These findings were our motivation to further investigate potential bioactive constituents in the $\mathrm{MeOH}$ extract of C. walteri. Hence, in this study, we performed advanced phytochemical analyses to examine the potential nephroprotective constituents of the $\mathrm{MeOH}$ extract of $C$. walteri, leading to the successful isolation of 15 compounds (1-15). We therefore report the isolation and structural elucidation of these compounds and the evaluation of their protective effects against cisplatin-induced nephrotoxicity in renal tubular epithelial (LLC-PK1) cells. 


\section{Results and discussion}

C. walteri stems and stem barks collected from Jeju Island, Korea were extracted with $80 \%$ aqueous $\mathrm{MeOH}$ under reflux, and then evaporated under a vacuum to obtain a $\mathrm{MeOH}$ crude extract, which was subsequently solvent-fractionated with hexane, $\mathrm{CHCl}_{3}$, and $n-\mathrm{BuOH}$, yielding soluble fractions of each solvent. Significant spots were detected in the hexane-soluble fraction after TLC analysis, and the hexane-soluble fraction was subjected to repeated column chromatography and HPLC purification, which resulted in the isolation of 15 compounds, including seven triterpenoids (1-7), five steroids (8-12), two diterpene analogs (13 and 14), and one phenolic compound (15). Based on a comparison of their spectroscopic (including ${ }^{1} \mathrm{H}$ and ${ }^{13} \mathrm{C} \mathrm{NMR}$ ) and physical data with previously reported values and LC/MS analyses, the chemical structures of all the isolates were determined and identified as: leucophyllone (1), ${ }^{\mathbf{1 1}}$ 3-O-acetylbetulin (2), ${ }^{20}$ betulinic acid methyl ester (3), ${ }^{21}$ lupenone (4), ${ }^{22}$ methyl 3-O-acetylbetulinate (5), ${ }^{23}$ lupeol (6), ${ }^{24}$ betulinic acid (7), ${ }^{25} 6 \beta$-hydroxysitostenone (8), ${ }^{26}$ sitostenone (9), ${ }^{27} 5 \alpha$ stigmast-3,6-dione (10), ${ }^{28} \quad 3 \beta$-sitostanol (11), ${ }^{29} \quad 6 \alpha$-hydroxy- $\beta$ sitostenone (12), ${ }^{30}$ norphytan (13), ${ }^{31}$ phytone (14), ${ }^{32}$ and benzyl salicylate (15) ${ }^{33}$ (Fig. 1A).

Renal tubular cell death induced by oxidative stress and apoptosis is a common feature of cisplatin-induced
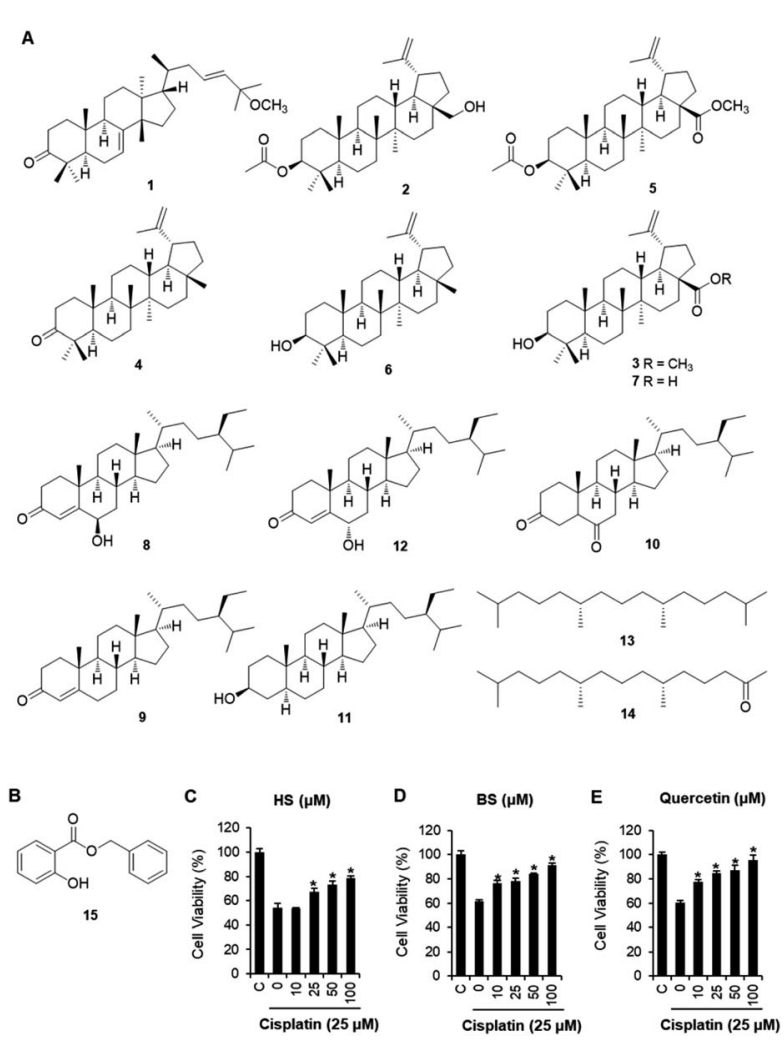

Fig. 1 Chemical structures of compounds 1-14 (A) and benzyl salicylate (BS) (15) (B). Protective effects of 6 $\beta$-hydroxysitostenone (HS) (8) and BS (15), and quercetin (positive control, (E)) on the viability of cisplatin-damaged LLC-PK1 cells for $24 \mathrm{~h}$, evaluated via the MTT assay (C and D). ${ }^{*} p<0.05$ vs. the cisplatin-treated cells. nephrotoxicity. ${ }^{\mathbf{4} 34}$ The effects of cisplatin and/or compounds isolated from $C$. walteri on cell viability were determined using the Ez-Cytox (tetrazolium salt, WST-1) cell viability assay. Among the isolated compounds (1-15) tested, 6 $\beta$-hydroxysitostenone (HS) (8) and benzyl salicylate (BS) (15) displayed significant protective effects against cisplatin-induced renal tubular epithelial cell damage (Fig. S1 $\dagger$ ). As shown in Fig. 1, an approximately $40 \%$ significant decrease in cell viability was observed in the $25 \mu \mathrm{M}$ cisplatin-treated group compared with the control group ( $100 \%$ cell viability). Meanwhile, co-treatment with HS $(25,50$, and $100 \mu \mathrm{M})$ and BS $(10,25,50$, and $100 \mu \mathrm{M})$ significantly increased cell viability to $78.5 \pm 1.6 \%$ and $91.4 \pm$ $1.2 \%$, respectively, compared with the respective cisplatintreated groups (Fig. 1). Interestingly, $100 \mu \mathrm{M}$ BS was as potent as $100 \mu \mathrm{M}$ quercetin, a frequently studied compound with excellent antioxidant properties in in vivo and in vitro models of cisplatin-induced nephrotoxicity (Fig. 1). ${ }^{35-38}$

To determine the effects of BS $(50$ and $100 \mu \mathrm{M})$ on cisplatininduced LLC-PK1 cell morphological changes and nuclear condensation, Hoechst 33342 staining was used. As shown in Fig. 2A, no changes were observed in the control group, whereas the cisplatin-treated group showed changes in cell shape and structure such as shrinkage as well as round and blebbing morphology. Furthermore, fluorescence microscopy images of the cisplatin-treated group had a higher bright bluefluorescence, compared with the control group (Fig. 2B). Conversely, the BS-treated (50 and $100 \mu \mathrm{M}$ ) LLC-PK1 cells revealed attenuation of the cisplatin-induced changes in their cell shape, structure, and nuclear condensation, which were changes leading to apoptotic cell death (Fig. 2). ${ }^{39}$

ROS generation is one of the potential mechanisms for cisplatin-induced renal tubular epithelial cell damage and a hallmark of the induction of apoptosis. ${ }^{\mathbf{4 0 , 4 1}}$ The effects of cisplatin and/or BS on ROS generation were determined using $\mathrm{H}_{2}$ DCFDA ( $2^{\prime}, 7^{\prime}$-dichlorodihydrofluorescein diacetate). As indicated in Fig. 3A, fluorescence microscopy images of the cisplatin-treated group had a higher bright green-fluorescence compared with the control group because nonfluorescent

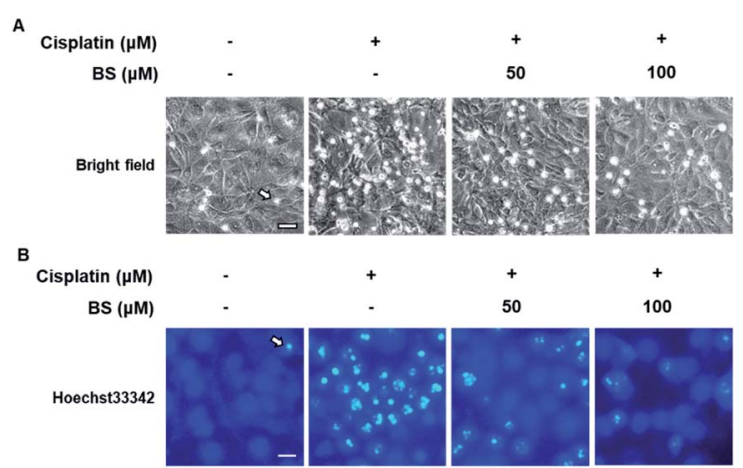

Fig. 2 Effects of benzyl salicylate (BS) on cisplatin-induced morphological changes and nuclear condensation in LLC-PK1 cells. (A) Representative phase contrast microscopy images of cells. (B) Representative fluorescence microscopy images of cells stained with Hoechst 33342. Scale bar, $50 \mu \mathrm{m}$. 


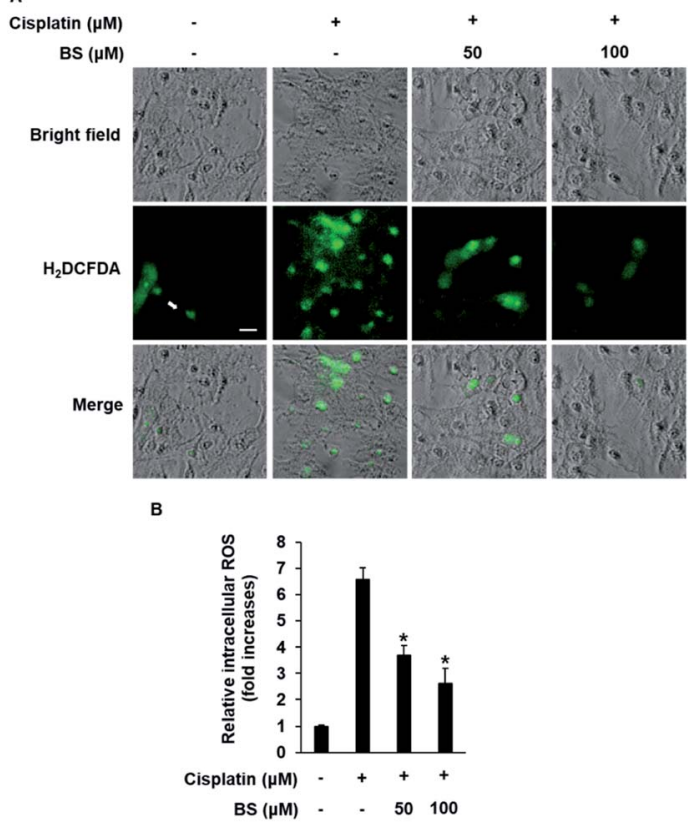

Fig. 3 Effect of BS on cisplatin-induced oxidative stress in LLC-PK1 cells. (A) Accumulation of ROS visualized with $\mathrm{H}_{2}$ DCFDA. Scale bar, 50 $\mu \mathrm{m}$. (B) Bar graph showing the fold increase in the intracellular ROS accumulation. ${ }^{*} p<0.05$ vs. the cisplatin-treated cells.

$\mathrm{H}_{2}$ DCFDA is converted to the fluorescent $2^{\prime}, 7^{\prime}$-dichlorofluorescein (DCF) upon oxidation by ROS, whereas the BStreated (50 and $100 \mu \mathrm{M}$ ) LLC-PK1 cells revealed attenuation of cisplatin-induced elevated intracellular ROS. As shown in Fig. 3B, quantitative analyses showed that the cisplatin-induced elevated intracellular ROS levels (7.37-fold increase) were significantly reduced by BS (50 and $100 \mu \mathrm{M})(4.20$ - and 2.68 -fold increases, respectively). Cisplatin intensifies the generation of kidney oxidative stress, associated with the decrease of proximal tubule cell viability through mitochondria and DNA dysfunction. ${ }^{5}$ Therefore, BS is a promising antioxidant agent for cisplatin-induced oxidative stress. The finding is in accordance with the study reported previously where quercetin showed the nephroprotective effect in cisplatin-treated rats because of its radical scavenging activity in the kidney tubular cells of rats. ${ }^{35}$

The protective effects of BS $(50$ and $100 \mu \mathrm{M})$ were investigated on cisplatin-induced cell death process in LLC-PK1 cells using staining with annexin V conjugated with Alexa Fluor 488 that can detect phosphatidylserine on the cell surface of apoptotic cells and propidium iodide (PI) that can detect necrotic cells by staining DNA and RNA inside of necrotic cells. Increased apoptosis (bright green color) was observed in the cisplatin-treated group compared with the control group (Fig. 4A). Conversely, the BS-treated (50 and $100 \mu \mathrm{M}$ ) LLC-PK1 cells attenuated the cisplatin-induced apoptosis. These results indicate that BS (50 and $100 \mu \mathrm{M})$ protects against cisplatininduced LLC-PK1 cell death by inhibiting apoptosis. Quantitative analyses showed a significant $61.45 \pm 4.78 \%$ increase in the percentage of apoptotic cells stained with annexin $\mathrm{V}$ in the 25 $\mu \mathrm{M}$ cisplatin-treated group compared with the control group

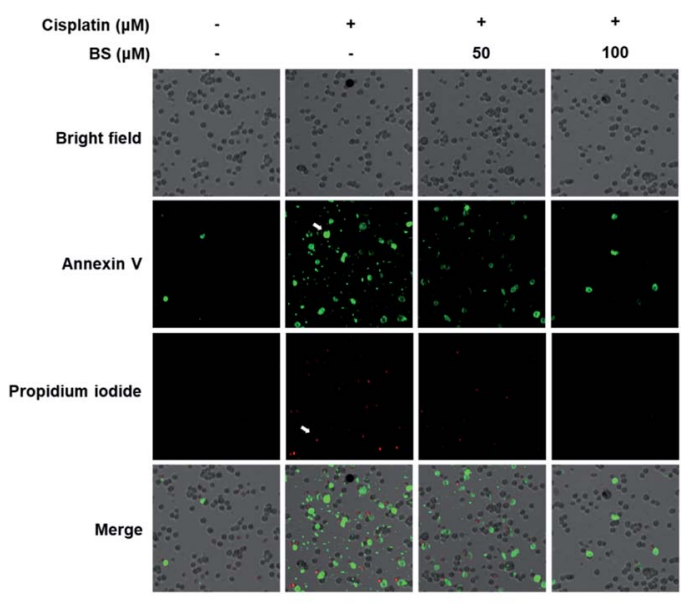

B

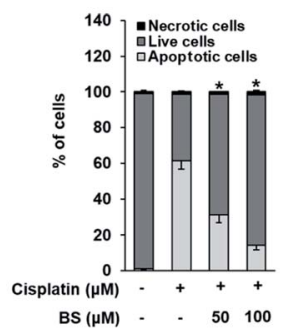

Fig. 4 Effect of BS on cisplatin-induced apoptosis in LLC-PK1 cells. (A) Visualization of apoptotic (green circles), live, and necrotic cells (red circles) cells (40x magnification). (B) Bar graph showing percentage of percentage of apoptotic, live, and necrotic cells. ${ }^{*} p<0.05$ vs. cisplatintreated cells.

(1.25 \pm 0.52\%; Fig. 4B). Conversely, BS treatment (50 and 100 $\mu \mathrm{M})$ significantly decreased the percentage of apoptotic cells to $30.91 \pm 4.09 \%$ and $14.20 \pm 2.40 \%$, respectively, compared with the cisplatin-treated group. In addition, quantitative analyses showed a significant decrease in the percentage of live cells in the $25 \mu \mathrm{M}$ cisplatin-treated group $(37.21 \pm 0.05 \%)$ compared with the control group ( $97.75 \pm 0.01 \%$; Fig. 4B). Conversely, 50 and $100 \mu \mathrm{M}$ BS treatments significantly increased the percentage of live cells to $67.75 \pm 0.05 \%$ and $84.13 \pm 0.03 \%$, respectively, compared with the cisplatin-treated group. Percentage of necrotic cells stained with PI did not show significant changes. These results indicate that BS inhibited cisplatin-induced apoptosis. The finding is in agreement with earlier studies, where low concentration of cisplatin induces apoptotic cell death, whereas higher concentration of cisplatin induces necrotic cell death. ${ }^{42}$

To investigate the protective effects of BS (50 and $100 \mu \mathrm{M})$ on the underlying apoptotic pathway, we focused on evaluating the regulation of the mitogen-activated protein kinase (MAPK) pathways such as extracellular signal-regulated kinases (ERK), c-Jun N-terminal kinases (JNK), and p38. ERK, JNK, and p38 are important for the stress response and cell death, thus, are essential factors in cisplatin-induced apoptosis in renal tubular epithelial cells. $^{34,43}$ A previous study revealed that the anti- 
apoptotic effect of quercetin in the cisplatin-treated rats is caused by suppression of the JNK. ${ }^{38}$ BS treatment (50 and 100 $\mu \mathrm{M})$ attenuated protein expression levels of MAPKs (p-JNK, pERK, and p-p38), compared with the levels in the cisplatintreated group (Fig. 5A). Overall, the observed downregulation of JNK, p-ERK, and p-p38 by BS treatment (50 and $100 \mu \mathrm{M})$ may be indicative of its protective, anti-apoptotic role in cisplatininduced LLC-PK1 cell damage.

We also investigated the effects of BS (50 and $100 \mu \mathrm{M})$ on Bax/Bcl-2 and cleaved caspase-8, -9 , and -3 activation. In the apoptosis pathway, the anti-apoptotic protein Bcl-2 and proapoptotic protein Bax are apoptotic regulatory proteins. Downregulation of Bcl-2 inhibits renal tubular epithelial cell death. When apoptosis is initiated, Bax is translocated to the mitochondrial membrane, leading to subsequent cisplatin-induced activation of caspases in renal tubular epithelial cells. ${ }^{\mathbf{4 2 , 4 4}}$ Compared with the cisplatin-treated group, BS treatment (50 and $100 \mu \mathrm{M}$ ) significantly inhibited the expression of Bax and increased the expression of Bcl-2, which resulted in a decreased Bax/Bcl-2 ratio (Fig. 6A). In addition, activated initiator caspases-8, and -9, and executioner caspase-3 were observed in cisplatin-induced renal tubular epithelial cell death. ${ }^{\mathbf{4 2 , 4 5}}$ BS treatment (50 and $100 \mu \mathrm{M}$ ) significantly attenuated the protein expression of cleaved caspase- 9 and -3 , compared with the levels in the cisplatin-treated group. However, activation of caspase-8 were not regulated significantly by treatment of BS. Overall, our results indicate that $\mathrm{BS}$ treatment (50 and $100 \mu \mathrm{M}$ ) modulated

\section{A}

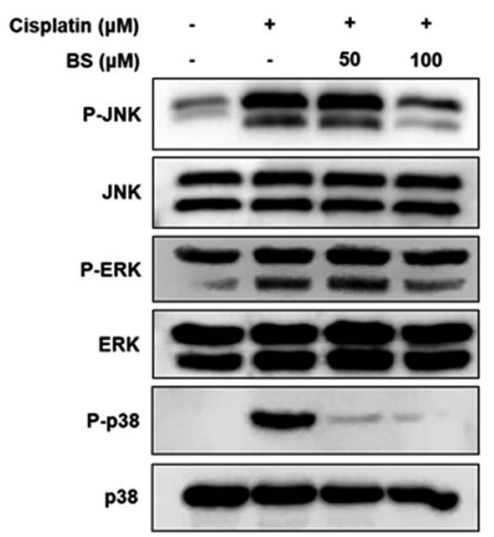

B

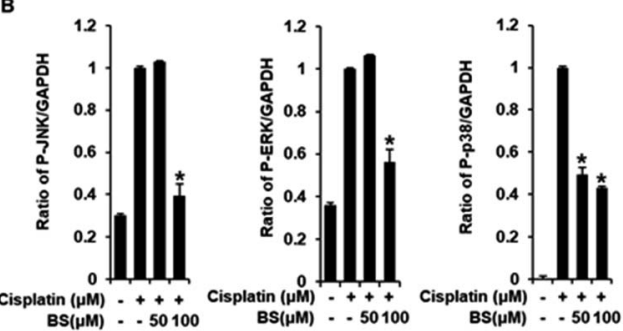

Fig. 5 Effects of BS on the levels of p-JNK, p-p38, and p-ERK in LLCPK1 cells with cisplatin-induced damage. Immunoreactive bands of (A) $p-J N K, p-p 38$, and $p$-ERK detected using western blot analyses. (B) Quantitative analyses of relative protein levels. ${ }^{*} p<0.05$ vs. the cisplatin-treated cells.

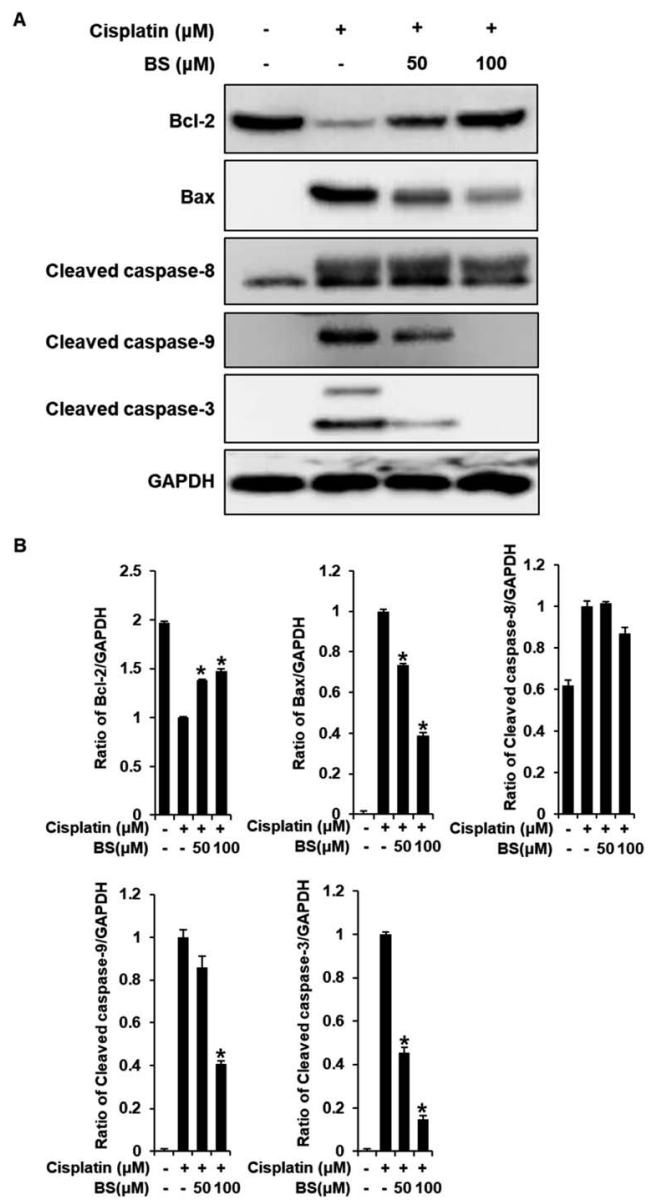

Fig. 6 Effects of BS on the levels of Bcl-2, Bax, cleaved caspase-3, -9, and -8 in LLC PK1 cells with cisplatin-induced damage. Immunoreactive bands of (A) Bcl-2, Bax, and cleaved caspase-8, -9, and -3 detected using western blot analyses. (B) Quantitative analyses of relative protein levels. ${ }^{*} p<0.05$ vs. the cisplatin-treated cells.

the $\mathrm{Bax} / \mathrm{Bcl}-2$ ratio by down-regulating the activation of caspase9 and -3 . Therefore, the protective effect of BS against cisplatininduced renal tubular epithelial cell damage was mediated through intrinsic apoptotic pathway.

\section{Conclusion}

In this study, we examined the potential of constituents of $C$. walteri against cisplatin-induced nephrotoxicity in LLC-PK1 cells, which led to the successful identification of the renoprotective compound benzyl salicylate (BS). BS inhibited cisplatininduced oxidative stress and apoptosis in renal tubular epithelial cells. In addition, the anti-apoptotic mechanism employed by BS was attributed to the regulation of the protein expression of Bax, Bcl-2, cleaved caspase- 9 and -3 . These results suggest BS as a novel promising renoprotective agent against cisplatin-induced nephrotoxicity. Furthermore, further in vivo and in vitro studies are required to validate the mechanisms by which BS protects against cisplatin-induced renal tubular epithelial cell death. Our present study further supported the 
potential of BS as a promising therapeutic candidate that benefits to nephroprotective effects.

\section{Experimental section}

\section{General experimental procedures}

Optical rotations were measured using a Jasco P-1020 polarimeter (Jasco, Easton, MD, USA). IR spectra were recorded with a Bruker IFS-66/S FT-IR spectrometer (Bruker, Karlsruhe, Germany). UV spectra were obtained using an Agilent 8453 UVvisible spectrophotometer (Agilent Technologies, Santa Clara, CA, USA). Nuclear magnetic resonance (NMR) spectra were recorded with a Bruker AVANCE III 700 NMR spectrometer operating at $500 \mathrm{MHz}\left({ }^{1} \mathrm{H}\right)$ and $125 \mathrm{MHz}\left({ }^{13} \mathrm{C}\right)$ (Bruker, Karlsruhe, Germany). Semi-preparative HPLC was performed using a Gilson 306 pump with a Shodex refractive index detector at a flow rate of $2 \mathrm{~mL} \mathrm{~min}{ }^{-1}$. LC/MS analyses were performed on an Agilent 1200 Series HPLC system equipped with a diode array detector and 6130 Series ESI mass spectrometer, using an analytical Kinetex C18 $100 \AA$ column $(100 \times 2.1 \mathrm{~mm}$ i.d, $5 \mu \mathrm{m}$; Phenomenex, Torrance, CA, USA). Silica gel 60 (70-230 mesh and 230-400 mesh; Merck, Darmstadt, Germany) and RP-C 18 silica gel (Merck, 40-63 $\mu \mathrm{m}$ ) were used for column chromatography. Merck precoated silica gel $F_{254}$ plates and RP-18 $F_{254 s}$ plates were used for TLC. Spots were detected after TLC under UV light or by heating after spraying with anisaldehyde-sulfuric acid.

\section{Plant material}

C. walteri stems and stem barks were collected from Jeju Island, Korea, in October 2005, and identified by one of the authors (K. H. Kim). A voucher specimen (SKKU 2005-10a) was deposited at the herbarium of the School of Pharmacy, Sungkyunkwan University, Suwon, Korea.

\section{Extraction and isolation}

C. walteri stems and stem barks ( $2.5 \mathrm{~kg})$ were dried, chopped, and crude extracts were prepared using $80 \%$ aqueous $\mathrm{MeOH}(2$ $\times 6 \mathrm{~h}$ ) under reflux, and then filtered. The filtrate was evaporated under a vacuum to obtain a $\mathrm{MeOH}$ extract $(220 \mathrm{~g})$, which was suspended in distilled $\mathrm{H}_{2} \mathrm{O}(7.2 \mathrm{~L})$ and then successively partitioned with hexane, $\mathrm{CHCl}_{3}$, and $n$-BuOH, yielding 9.5, 25.0, and $43.0 \mathrm{~g}$ of residue, respectively. The hexane-soluble fraction $(9.5 \mathrm{~g})$ was chromatographed on a silica gel $(230-400$ mesh, 300 g) column eluted with hexane-EtOAc $(3: 1$ to $1: 1$, gradient system), to yield fractions H1-H5. Fraction H1 (4.0 g) was separated using an $\mathrm{RP}^{-\mathrm{C}_{18}}$ silica gel column using $100 \% \mathrm{MeOH}$, to acquire five fractions (H11-H15). Fraction H12 (800 mg) was subjected to a Sephadex LH-20 column using a solvent system of dichloromethane-MeOH $(1: 1)$, to give subfractions H121H122. To obtain compound 15 (12 mg), fraction H122 (50 mg) was subjected to a silica gel Waters Sep-Pak Vac $6 \mathrm{cc}$ with hexane-EtOAc $(30: 1)$. Fraction $\mathrm{H} 13(800 \mathrm{mg})$ was further separated using silica gel column chromatography eluting a gradient solvent system of hexane-EtOAc $(7: 1$ to $1: 1, \mathrm{v} / \mathrm{v})$, to provide 6 subfractions (H131-H136). Compound 12 (6 mg) was purified from subfraction H131 (100 mg) using semipreparative normal-phase HPLC (Apollo Silica column, $250 \times$ $10.0 \mathrm{~mm}, 5 \mu \mathrm{m}$, flow rate: $2 \mu \mathrm{mL} \mathrm{min}^{-1}$ ) and eluted with an isocratic solvent system of hexane-EtOAc $(18: 1$, v/v). Five subfractions (H141-H145) were acquired from fraction H14 (300 mg) using silica gel column chromatography with a gradient solvent system of hexane-EtOAc $(16: 1$ to $1: 1, \mathrm{v} / \mathrm{v})$. To obtain compound $2(40 \mathrm{mg})$, subfraction H142 $(50 \mathrm{mg})$ was isolated using semi-preparative normal-phase HPLC (Apollo Silica column, $250 \times 10.0 \mathrm{~mm}, 5 \mu \mathrm{m}$, flow rate: $2 \mathrm{~mL} \mathrm{~min}^{-1}$ ) with an isocratic solvent system of hexane-EtOAc $(28: 1, \mathrm{v} / \mathrm{v})$. Compound $13(30 \mathrm{mg})$ was obtained from subfraction H144 (50 mg) using semi-preparative normal-phase HPLC (Apollo

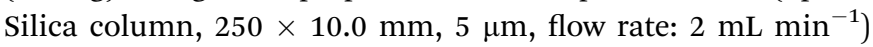
eluted with an isocratic solvent system of hexane-EtOAc $(12: 1$, $\mathrm{v} / \mathrm{v})$. To obtain compound $3(7 \mathrm{mg})$, fraction $\mathrm{H} 15(100 \mathrm{mg})$ was separated using a C18 Sep-Pak column eluting an isocratic solvent system of hexane-EtOAc $(10: 1, \mathrm{v} / \mathrm{v})$ and further isolated using semi-preparative normal-phase HPLC (Apollo Silica column, $250 \times 10.0 \mathrm{~mm}, 5 \mu \mathrm{m}$, flow rate: $2 \mathrm{~mL} \mathrm{~min}^{-1}$ ) with an isocratic solvent system of hexane-EtOAc $(20: 1, \mathrm{v} / \mathrm{v})$. Fraction $\mathrm{H} 2(2.5 \mathrm{~g})$ was loaded onto an $\mathrm{RP}^{-\mathrm{C}_{18}}$ silica gel column and separated by eluting with $100 \% \mathrm{MeOH}$ to obtain eight fractions (H21-H28). Compound $8(60 \mathrm{mg})$ was isolated from fraction H27 (150 mg) using semi-preparative normal-phase HPLC (Apollo Silica column, $250 \times 10.0 \mathrm{~mm}, 5 \mu \mathrm{m}$, flow rate: 2 $\mathrm{mL} \mathrm{min}^{-1}$ ) with an isocratic solvent system of hexane-EtOAc $(8: 1, \mathrm{v} / \mathrm{v})$. Fraction $\mathrm{H} 28(100 \mathrm{mg})$ was isolated using semipreparative normal-phase HPLC (Apollo Silica column, $250 \times$

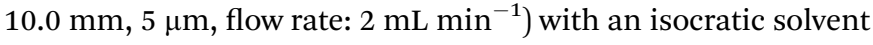
system of hexane-EtOAc $(8: 1, \mathrm{v} / \mathrm{v})$ to obtain compound 7 (25 $\mathrm{mg})$. Fraction $\mathrm{H} 3\left(1.7 \mathrm{~g}\right.$ ) was loaded onto an $\mathrm{RP}^{-\mathrm{C}_{18}}$ silica gel column and fractionated by eluting with $100 \% \mathrm{MeOH}$ to obtain six fractions (H31-H36). Fraction H32 (200 mg) was separated by reverse-phase Lobar column with an isocratic solvent system of hexane-EtOAc $(4: 1, \mathrm{v} / \mathrm{v})$ to obtain four subfractions (H321H324). Compound $5(4 \mathrm{mg})$ was obtained from subfraction H321 (150 mg) using semi-preparative reverse-phase HPLC (Econosil C18 column, $250 \times 10.0 \mathrm{~mm}, 5 \mu \mathrm{m}$, flow rate: 2 $\mathrm{mL} \min ^{-1}$ ) eluting with an isocratic solvent system of $95 \%$ $\mathrm{MeOH}$. Fraction H33 (400 mg) was fractionated using a reversephase Lobar column with an isocratic solvent system of hexaneEtOAc $(4: 1, \mathrm{v} / \mathrm{v})$ to obtain five subfractions (H331-H335). Fraction $\mathrm{H} 331(50 \mathrm{mg})$ was purified using semi-preparative reverse-phase HPLC (Econosil C18 column, $250 \times 10.0 \mathrm{~mm}, 5$ $\mu \mathrm{m}$, flow rate: $2 \mathrm{~mL} \mathrm{~min}^{-1}$ ) with an isocratic solvent system of $100 \% \mathrm{MeOH}$ to give compound 1 (7 mg). Compound $14(30 \mathrm{mg})$ was obtained from fraction $\mathrm{H} 34(120 \mathrm{mg})$ using semipreparative normal-phase HPLC (Apollo Silica column, $250 \times$

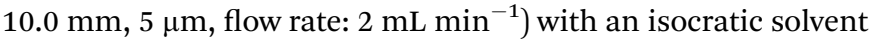
system of hexane-EtOAc $(3: 1, \mathrm{v} / \mathrm{v})$. Compounds $\mathbf{9}(5 \mathrm{mg})$ and 10 (8 mg) were purified from fraction $\mathrm{H} 36(120 \mathrm{mg})$ using semipreparative normal-phase HPLC (Apollo Silica column, $250 \times$ $10.0 \mathrm{~mm}, 5 \mu \mathrm{m}$, flow rate: $2 \mathrm{~mL} \mathrm{~min}^{-1}$ ) with an isocratic solvent system of hexane-EtOAc $(4: 1, \mathrm{v} / \mathrm{v})$. Fraction $\mathrm{H} 4(1.3 \mathrm{~g})$ was loaded onto an RP- $_{18}$ silica gel column and fractionated by eluting with $100 \% \mathrm{MeOH}$ to give six fractions ( $\mathrm{H} 41-\mathrm{H} 46)$. 
Fraction H44 (120 mg) was isolated using semi-preparative normal-phase HPLC (Apollo Silica column, $250 \times 10.0 \mathrm{~mm}, 5$

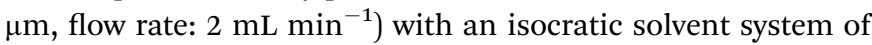
hexane-EtOAc $(2: 1, \mathrm{v} / \mathrm{v})$ to obtain compounds $4(5 \mathrm{mg})$ and 6 (25 mg). Fraction H5 (500 mg) was fractionated using an RP-C18 silica gel column with an isocratic solvent system of $85 \% \mathrm{MeOH}$ to obtain five fractions (H51-H55). Fraction H51 (150 mg) was passed over the Sephadex-LH20 column with $\mathrm{CHCl}_{3}-\mathrm{MeOH}$ $(1: 1, \mathrm{v} / \mathrm{v})$ and further purified using semi-preparative reversephase HPLC (Econosil C18 column, $250 \times 10.0 \mathrm{~mm}, 5 \mu \mathrm{m}$, flow rate: $2 \mathrm{~mL} \mathrm{~min}^{-1}$ ) eluting with an isocratic solvent system of $100 \% \mathrm{MeOH}$ to obtain compound 11 (6 mg).

\section{Cell culture}

The pig kidney epithelial cell line (LLC-PK1) was used to investigate the nephroprotective effect against cisplatininduced renal cell damage. LLC-PK1 cells were purchased (American Type Culture Collection, Rockville, MD, USA) and grown to $80 \%$ confluence with DMEM containing $10 \%$ FBS, $1 \%$ penicillin/streptomycin, and $4 \mathrm{mM}$ L-glutamine at $37{ }^{\circ} \mathrm{C}$ with $5 \%$ carbon dioxide and $95 \%$ relative humidity.

\section{Renoprotective effect against cisplatin-induced kidney cell damage}

LLC-PK1 cells were plated onto 96-well culture plates $\left(1 \times 10^{4}\right.$ cells per well). After $24 \mathrm{~h}$, they were exposed to various concentrations of the isolated compounds in the presence of 25 $\mu \mathrm{M}$ cisplatin for $24 \mathrm{~h}$. The relative percent cell viability was assessed with the Ez-Cytox reagent kit (Daeil Lab Service, Seoul, Korea), following the manufacturer's instructions. The optical densities (OD) were measured at $450 \mathrm{~nm}$ using a microplate reader (PowerWave XS; Bio-Tek Instruments, Winooski, VT, USA).

\section{Determination of intracellular ROS}

The cells were plated onto 6-well culture plates $\left(1 \times 10^{4}\right.$ cells per well). After $24 \mathrm{~h}$, they were exposed to 50 or $100 \mu \mathrm{M}$ benzyl salicylate (BS) in the presence of $25 \mu \mathrm{M}$ cisplatin for $24 \mathrm{~h}$. The LLC-PK1 cells were then stained with $2^{\prime}, 7^{\prime}$-dichlorofluorescin diacetate $\left(\mathrm{H}_{2}\right.$ DCFDA; Sigma Aldrich, St. Louis, MO, USA) for $30 \mathrm{~min}$ at $37{ }^{\circ} \mathrm{C}$ and then washed with PBS. The cells were visualized under the IX50 fluorescent microscope (Olympus, Tokyo, Japan) equipped with a CCD camera, and fluorescence intensities of DCF at $495 \mathrm{~nm}$ excitation and $517 \mathrm{~nm}$ emission were measured using a fluorescence microplate reader (SPARK 10M; Tecan, Männedorf, Switzerland).

\section{Image-based cytometric assay}

To detect the apoptotic cell population, LLC-PK1 cells were plated onto 6-well culture plates $\left(4 \times 10^{5}\right.$ cells per well). After $24 \mathrm{~h}$, LLC-PK1 cells were treated with 50 or $100 \mu \mathrm{M}$ BS in the presence of $25 \mu \mathrm{M}$ cisplatin. The LLC-PK1 cells were then incubated with Annexin V-Alexa Fluor 488 and PI, following the manufacturer's instructions. The relative percentage of apoptotic, live, and necrotic cells was assessed with the Tali image-based cytometer (Invitrogen, Carlsbad, CA, USA).

\section{Western blotting}

The cells were plated into 6 -well culture plates $\left(4 \times 10^{5}\right.$ cells per well). After $24 \mathrm{~h}$, they were treated with 50 or $100 \mu \mathrm{M}$ BS in the presence of $25 \mu \mathrm{M}$ cisplatin. Following the manufacturer's instructions, the LLC-PK1 cells were then lysed with RIPA buffer (Cell Signaling Technology, MA, USA) supplemented with $1 \mathrm{mM}$ phenylmethylsulfonyl fluoride for $20 \mathrm{~min}$ at $4{ }^{\circ} \mathrm{C}$ to obtain the cell lysates.

The protein concentrations of cell lysates were quantified using the bicinchoninic acid (BCA) protein assay kit (Thermo Fisher Scientific, Waltham, MA, USA). Equal amounts of proteins $(20 \mu \mathrm{g}$ of protein/lane) were separated using electrophoresis in a precast $4-15 \%$ Mini-PROTEAN TGX gel (Bio-Rad, Hercules, CA, USA) and transferred to a polyvinylidene difluoride membrane (Merck Millipore, Darmstadt, Germany). Membranes were incubated overnight at $4{ }^{\circ} \mathrm{C}$ with rabbit antip44/42 MAPK (Erk1/2) antibody (1 : 1000; Cat. no. 4695S; Cell Signaling Technology, Inc., Beverly, MA, USA), rabbit antiphospho-p44/42 MAPK (Erk1/2) (Thr202/Tyr204) antibody (1 : 1000; Cat. no 8544S; Cell Signaling Technology, Inc.), rabbit anti-SAPK/JNK antibody (1 : 1000; Cat. no. 9252S; Cell Signaling Technology, Inc.), rabbit anti-phospho-SAPK/JNK (Thr183/ Tyr185) antibody (1:1000; Cat. no. 9251S; Cell Signaling Technology, Inc.), rabbit anti-p38 MAPK antibody (1 : 1000; Cat. no. 8690S; Cell Signaling Technology, Inc.), rabbit antiphospho-p38 MAPK (Thr180/Tyr182) antibody (1:1000; Cat. no. 4511S; Cell Signaling Technology, Inc.), rabbit anti-Bcl-2 antibody (1 : 1000; Cat. no. 3498S; Cell Signaling Technology, Inc.), rabbit anti-Bax antibody (1 : 1000; Cat. no. 14796S; Cell Signaling Technology, Inc.), rabbit anti-cleaved caspase-8 antibody (1 : 1000; Cat. no. 8592S; Cell Signaling Technology, Inc.), rabbit anti-cleaved caspase-9 antibody (1:1000; Cat. no. 20750S; Cell Signaling Technology, Inc.), rabbit anti-cleaved caspase-3 antibody (1:1000; Cat. no. 9664S; Cell Signaling Technology, Inc.), rabbit anti-GAPDH antibody (1 : 1000; Cat. no. 2118S; Cell Signaling Technology, Inc.), and anti-rabbit HRP-conjugated IgG (1 : 2000; Cat. no. 7074S; Cell Signaling Technology, Inc.). Protein bands were visualized with ECL Advance western blotting Detection Reagents (GE Healthcare, Cambridge, UK) and a FUSION Solo Chemiluminescence System (PEQLAB Biotechnologie GmbH, Erlangen, Germany).

\section{Statistical analyses}

Statistical significance was determined using analysis of variance (ANOVA), followed by a multiple comparison test with Bonferroni's adjustment. A $p$-value $<0.05$ was considered statistically significant.

\section{Conflicts of interest}

The authors declare no competing financial interests. 


\section{Acknowledgements}

This work was supported by the National Research Foundation of Korea (NRF) grant funded by the Korea government (MSIT) (2018R1A2B2006879 and 2019R1A5A2027340). This work was also supported by the Ministry of Education (NRF2012R1A5A2A28671860). We would like to thank Dr Young Hye Kim (Korea Basic Science Institute) for ESI-MS analysis.

\section{Notes and references}

1 W. Achkar, N. Abdulrahman, H. Al-Sulaiti, J. M. Joseph, S. Uddin and F. Mraiche, Cisplatin based therapy: the role of the mitogen activated protein kinase signaling pathway, J. Transl. Med., 2018, 16, 96.

2 A. M. Florea and D. Büsselberg, Cisplatin as an anti-tumor drug: cellular mechanisms of activity, drug resistance and induced side effects, Cancers, 2011, 3, 1351-1371.

3 L. Astolfi, S. Ghiselli, V. Guaran, M. Chicca, E. Simoni, E. Olivetto, G. Lelli and A. Martini, Correlation of adverse effects of cisplatin administration in patients affected by solid tumours: a retrospective evaluation, Oncol. Rep., 2013, 29, 1285-1292.

4 S. Y. Kim and A. Moon, Drug-induced nephrotoxicity and its biomarkers, Biomol. Ther., 2012, 20, 268-272.

5 F. Hayati, M. Hossainzadeh, S. Shayanpour, Z. AbediGheshlaghi and S. S. B. Mousavi, Prevention of cisplatin nephrotoxicity, J. Nephropharmacol., 2016, 5, 57-60.

6 S. Ojha, B. Venkataraman, A. Kurdi, E. Mahgoub, B. Sadek and M. Rajesh, Plant-derived agents for counteracting cisplatin-induced nephrotoxicity, Oxid. Med. Cell. Longevity, 2016, 2016, 27.

7 H. C. Park, T. K. Jung, M. J. Kim and K. S. Yoon, Protective effect of Cornus walteri Wangerin leaf against UVB irradiation induced photoaging in human reconstituted skin, J. Ethnopharmacol., 2016, 193, 445-449.

8 W. H. Choi, W. Y. Park, B. Y. Hwang, G. J. Oh, S. J. Kang, K. S. Lee and J. S. Ro, Phenolic compounds from the stem bark of Cornus walteri Wanger, Korean J. Pharmacogn., 1998, 29, 217-224.

9 D. Y. Lee, K. H. Yoo, I. S. Chung, J. Y. Kim, D. K. Chung, D. K. Kim, S. H. Kim and N. I. Baek, A new lignan glycoside from the fruits of Cornus kousa Burg, Arch. Pharmacal Res., 2008, 31, 830-833.

10 S. K. Vareed, R. E. Schutzki and M. G. Nair, Lipid peroxidation, cyclooxygenase enzyme and tumor cell proliferation inhibitory compounds in Cornus kousa fruits, Phytomedicine, 2007, 14, 706-709.

11 K. H. Kim, S. U. Choi, Y. C. Kim and K. R. Lee, Tirucallane triterpenoids from Cornus walteri, J. Nat. Prod., 2011, 74, 54-59.

12 E. J. Yang, E. Y. Yim, G. Song, G. O. Kim and C. G. Hyun, Inhibition of nitric oxide production in lipopolysaccharideactivated RAW 264.7 macrophages by Jeju plant extracts, Interdiscip. Toxicol., 2009, 2, 245-249.

13 T. A. Trinh, E. J. Park, D. Lee, J. H. Song, H. L. Lee, K. H. Kim, Y. Kim, K. Jung, K. S. Kang and J. E. Yoo, Estrogenic activity of sanguiin H-6 through activation of estrogen receptor a coactivator-binding site, Nat. Prod. Sci., 2019, 25, 28-33.

14 S. C. Baek, E. Choi, H. J. Eom, M. S. Jo, S. Kim, H. M. So, S. H. Kim, K. S. Kang and K. H. Kim, LC/MS-based analysis of bioactive compounds from the bark of Betula platyphylla var. japonica and their effects on regulation of adipocyte and osteoblast differentiation, Nat. Prod. Sci., 2018, 24, 235-240.

15 S. Lee, S. Lee, H. Roh, S. S. Song, R. Ryoo, C. Pang, K. H. Baek and K. H. Kim, Cytotoxic constituents from the sclerotia of Poria cocos against human lung adenocarcinoma cells by inducing mitochondrial apoptosis, Cells, 2018, 7, 116.

16 J. S. Yu, H. S. Roh, K. H. Baek, S. Lee, S. Kim, H. M. So, E. Moon, C. Pang, T. S. Kang and K. H. Kim, Bioactivityguided isolation of ginsenosides from Korean Red Ginseng with cytotoxic activity against human lung adenocarcinoma cells, J. Ginseng Res., 2018, 42, 562-570.

17 H. M. So, H. J. Eom, D. Lee, S. Kim, K. S. Kang, I. K. Lee, K. H. Baek, J. Y. Park and K. H. Kim, Bioactivity evaluations of betulin identified from the bark of Betula platyphylla var. japonica for cancer therapy, Arch. Pharmacal Res., 2018, 41, 815-822.

18 K. H. Kim, Y. J. Shin, S. U. Choi and K. R. Lee, New cytotoxic $\delta$-valerolactones from Cornus walteri, Bull. Korean Chem. Soc., 2011, 32, 2443-2445.

19 S. R. Lee, J. W. Nam and K. H. Kim, New triterpenoids from the stems of Cornus walteri, Chem. Pharm. Bull., 2017, 65, 683-686.

20 R. C. Santos, J. A. R. Salvador, S. Marin and M. Cascante, Novel semisynthetic derivatives of betulin and betulinic acid with cytotoxic activity, Bioorg. Med. Chem., 2009, 17, 6241-6250.

21 L. Pohjala, S. Alakurtti, T. Ahola, J. Yli-Kauhaluoma and P. Tammela, Betulin-derived compounds as inhibitors of alphavirus replication, J. Nat. Prod., 2009, 72, 1917-1926.

22 P. Puapairoj, W. Naengchomnong, A. Kijjoa, M. M. Pinto, M. Pedro, M. S. J. Nascimento, A. M. S. Silva and W. Herz, Cytotoxic activity of lupane-type triterpenes from Glochidion sphaerogynum and Glochidion eriocarpum two of which induce apoptosis, Planta Med., 2005, 71, 208-213.

23 M. Urban, J. Sarek, J. Klinot and M. Hajduch, Synthesis of Aseco derivatives of betulinic acid with cytotoxic activity, $J$. Nat. Prod., 2004, 67, 1100-1105.

24 J. Fotie, D. S. Bohle, M. L. Leimanis, E. Georges, G. Rukunga and A. E. Nkengfack, Lupeol long-chain fatty acid esters with antimalarial activity from Holarrhena floribunda, J. Nat. Prod., 2006, 69, 62-67.

25 M. Sholichin, K. Yamasaki, R. Kasai and O. Tanaka, Carbon13 nuclear magnetic resonance of lupane-type triterpenes, lupeol, betulin and betulinic acid, Chem. Pharm. Bull, 1980, 28, 1006-1008.

26 M. Della Greca, P. Monaco and L. Previtera, Studies on aquatic plants. Part XVI. Stigmasterols from Typha latifolia, J. Nat. Prod., 1990, 53, 1430-1435.

27 S. Prachayasittikul, S. Suphapong, A. Worachartcheewan, R. Lawung, S. Ruchirawat and V. Prachayasittikul, 
Bioactive metabolites from Spilanthes acmella Murr, Molecules, 2009, 14, 850-867.

28 D. D. Zhang, J. Yang, J. F. Luo, X. N. Li, C. L. Long and Y. H. Wang, New aporphine alkaloids from the aerial parts of Piper semiimmersum, J. Asian Nat. Prod. Res., 2018, 20, 734-743.

29 Y. Arai, T. Hattori, N. Hamaguchi, K. Masuda, A. Takano and K. Shiojima, Fern constituents: dryocrassyl formate, sitostanyl formate and 12 $\alpha$-hydroxyfern-9(11)-ene from Cyathea podophylla, Chem. Pharm. Bull., 2003, 51, 1311-1313.

30 L. K. Wang, C. J. Zheng, X. B. Li, G. Y. Chen, C. R. Han, W. H. Chen and X. P. Song, Two new lanostane triterpenoids from the branches and leaves of Polyalthia obliqua, Molecules, 2014, 19, 7621-7628.

31 D. K. Dalling, R. J. Pugmire, D. M. Grant and W. E. Hull, The use of high-field carbon-13 NMR spectroscopy to characterize chiral centers in isopranes, Magn. Reson. Chem., 1986, 24, 191-198.

32 L. Zhao, C. Jin, Z. Mao, M. B. Gopinathan, K. Rehder and R. D. Brinton, Design, synthesis, and estrogenic activity of a novel estrogen receptor modulator-a hybrid structure of $17 \beta$-estradiol and vitamin $\mathrm{E}$ in hippocampal neurons, $J$. Med. Chem., 2007, 50, 4471-4481.

33 V. P. Talzi, A ${ }^{13} \mathrm{C}$ and ${ }^{1} \mathrm{H}$ NMR analysis of perfumes, Russ. J. Appl. Chem., 2006, 79, 107-116.

34 G. S. Oh, H. J. Kim, A. Shen, S. B. Lee, D. Khadka, A. Pandit and H. S. So, Cisplatin-induced kidney dysfunction and perspectives on improving treatment strategies, Electrolytes Blood Pressure, 2014, 12, 55-65.

35 S. Ilić, N. Stojiljković, M. Veljković, S. Veljković and G. Stojanovic, Protective effect of quercetin on cisplatininduced nephrotoxicity in rats, Facta Univ. - Ser. Med. Biol., 2014, 16, 71-75.
36 M. Aldemir, E. Okulu, K. Kösemehmetoğlu, K. Ener, F. Topal, O. Evirgen, E. Gürleyik and A. Avcı, Evaluation of the protective effect of quercetin against cisplatin-induced renal and testis tissue damage and sperm parameters in rats, Andrologia, 2014, 46, 1089-1097.

37 P. S. Devi and D. C. Shyamala, Protective effect of quercetin in cisplatin-induced cell injury in the rat kidney, Indian $J$. Pharmacol., 1999, 31, 422-426.

38 H. D. C. Francescato, T. M. Coimbra, R. S. Costa and M. L. P. Blanchi, Protective effect of quercetin on the evolution of cisplatin-induced acute tubular necrosis, Kidney Blood Pressure Res., 2004, 27, 148-158.

39 G. Häcker, The morphology of apoptosis, Cell Tissue Res., 2000, 301, 5-17.

40 E. Ozbek, Induction of oxidative stress in kidney, Int. J. Nephrol., 2012, 2012, 465897.

41 H. Soni, D. Kaminski, R. Gangaraju and A. Adebiyi, Cisplatin-induced oxidative stress stimulates renal Fas ligand shedding, Renal Failure, 2018, 40, 314-322.

42 M. H. Hanigan and P. Devarajan, Cisplatin nephrotoxicity: molecular mechanisms, Cancer Ther., 2003, 1, 47-61.

43 H. Cassidy, R. Radford, J. Slyne, S. O Connell, C. Slattery, M. P. Ryan and T. McMorrow, The role of MAPK in druginduced kidney injury, J. Signal Transduction, 2012, 2012, 463617.

44 Q. Wei, G. Dong, J. Franklin and Z. Dong, The pathological role of Bax in cisplatin nephrotoxicity, Kidney Int., 2007, 72, 53-62.

45 G. P. Kaushal, V. Kaushal, X. Hong and S. V. Shah, Role and regulation of activation of caspases in cisplatin-induced injury to renal tubular epithelial cells, Kidney Int., 2001, 60, 1726-1736. 